\title{
KOVÁCS Zoltán
}

\section{ELLÁTÁSI LÁNCOK IRÁNYÍTÁSI ALGORITMUSAI A SÖRJÁTÉK PÉLDÁJÁN}

A sörjáték egy szimulációs eszköz, amely rendszerdinamikai sajátosságok bemutatására szolgál egy egyszerúsített ellátásilánc-modell alkalmazásával. A szerzố ennek egy továbbfejlesztett, véletlenszerú igényt tartalmazó változatát használja. A cikkben öt irányítási algoritmust mutat be: 1. visszacsatolást nem tartalmazó, vezérlés jellegú mechanizmus, ami állandó rendelési idốközt és állandó rendelési mennyiséget alkalmaz, 2. közvetlen visszacsatolás, 3. két beavatkozási határértéket tartalmazó állásos szabályozás, 4. egy célértéket tartalmazó visszacsatolás, 5. elốrejelzésen alapuló elórecsatolás. Az elemzések részben lejátszott játékok felhasználásával, részben pedig Monte Carlo szimulációval történtek.

Kulcsszavak: ellátásilánc-menedzsment, sörjáték, üzleti szimuláció, rendszerdinamika, irányítási rendszer, szabályozás

Az ellátási lánc értékteremtố folyamatok együttmúködó vállalatokon átíveló sorozata, mely vevôi igények kielégítésére alkalmas termékeket, illetve szolgáltatásoka hoz létre (Chikán, 1999). Ezt az „átivelést" természetesen nem vallalatok felett, hanem az ellátási láncban rés vevố vâllalatokon keresztul értelmezzûk. Az együttmúk dés érdekében elơfordul, hogy az egyébként onálló vál latok szuverenitásuk egy részéról lemondanak, például beszállítóvá válás érdekében.

Ilyen módon vállalatok feletti irányítási mechanizmusok is érvényesülnek.

Martin Christopher szerint ,manapság nem vállalatok, hanem ellátási láncok versenyeznek a piacon". A láncok

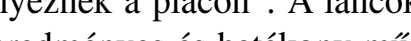
ködéścz meg kell tal ködéséhez meg kell találni és alkalmazni kell azon módszerek negfeleloit, amelyeket vállalati, vagy azon belüli rendszerek vizsgálatához, a múködés optimalizálásához alkalmazhatunk

A problémakör összetettsége miatt ebben az esetben a szokásosnál nagyobb hangsúlyt kap a szimuláció.

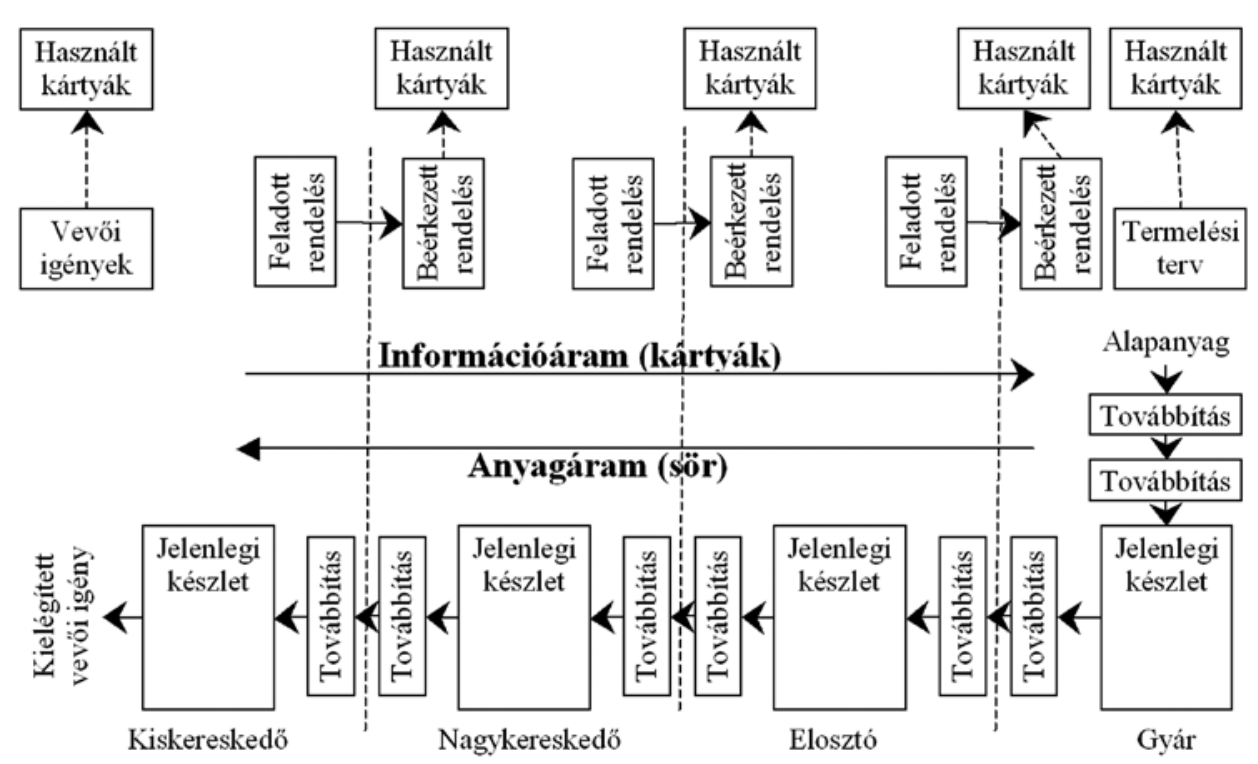

VEZETÉSTUDOMÁNY

\section{A sörjáték}

Az MIT-n kifejlesztett sörjáték egy olyan ellátási láncot szimulál, amelyben négy vállalaton keresztül áramlik az áru az előállítótól a vevôhöz. A vállalatok egymástól rendelnek, rendelkezhetnek készlettel, rendelés eljuttatásának és a közöttuik lévő szállításnak idốigénye van. Egy játék elrendezése az 1. ábrán látható.

\section{A sörjáték elrendezése}

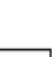

A játéknak jelentôs nemzetközi irodalma van (Forrester, 1961; Senge, 1990; Sterman, 1992; Coakley et al., 1998; D' Atri et al., 2009; Goodwin - Franklin, 1994; Noy et al., 2006; Kumar - Chandra - Seppanen, 2007), ezért most részletesen nem mutatjuk be.

A játék látszólag egyszerú: állandó vevôi igényt kell kielégíteni korlátlan kapacitásviszonyok és az adott időszaki helyi rendelésre korlátozott információ-ellátottság mellett.

A szimulációs játék lefutása után azonban - a résztvevók számára meglepő módon - a rendszer mutatói erôteljes idóbli ingón món -a rendszer múszinak, - készleta ségek nehezn indokolhatón magasak lesznek. A múködés akadozik, például a rendszerben egyidejúleg fordul eló készlet és hiány.

A jatéknak elkészitetuk a sztochasztikus igényt tartalmazó változatát, ennek tapasztalatait egy korábbi publikációban mutattuk be (Kovács, 2010). Goetgeluk (2006) ugyancsak vizsgálta sztochasztikus verziójú játékok irányítási kérdéseit, sztochasztikus programozási példákként ellátási láncokban, többféle szcenárió esetén.

Amíg a determinisztikus eset irányítása - a játék tapasztalatainak ismeretében - egyszerú, hiszen a JITelvet célszerú alkalmazni, addig sztochasztikus esetben felmerül az algoritmusválasztás és a választott algoritmus paramétereinek beállítási kérdése. Ezen algoritmusok egy részét magában a játékban próbáltuk ki, másokat - elsősorban az idóigényeseket - Monte Carlo szimulációval értékeltük.

\section{Az irányítási probléma megfogalmazása}

Ahogyan az 1. ábrán látható, a rendszerben négy beavatkozási hely van. Rovid logikai úton el lehet jutni ar a következtetésre, hogy a rendszer optimális múködtetése olyan esethez rendelhetố, amikor készlet csak a kiskereskedônél van, a többi hely JIT szerint múködik, tehát rendeléseiket összehangolják. A modell egy egykészletes esetre egyszerúsödik, de a távoli beavatkozási hely - gyár - miatt a holtidó megmarad. Egyedüli döntési - máltozó - szabályozott jellemzó - a gyártandó változo - szabályozott jellemzó - a gyártandó mennyiség, ami bizonyos késéssel a készlet bemenete lesz. A csak kiskereskedói készletet az
indokolja, hogy a készlet helye a rendszerszintú költségeket nem, de a rendszer válaszidejét, ezáltal pedig a hiány kockázatát befolyásolja. Miné távolabb van a készlet a végfelhasználótól, anná nagyobb a válaszidô, és annál nagyobb a hiány kockázata, és ebből adódóan az összes hiánykölt-
A rendszer átmeneti fügovénye

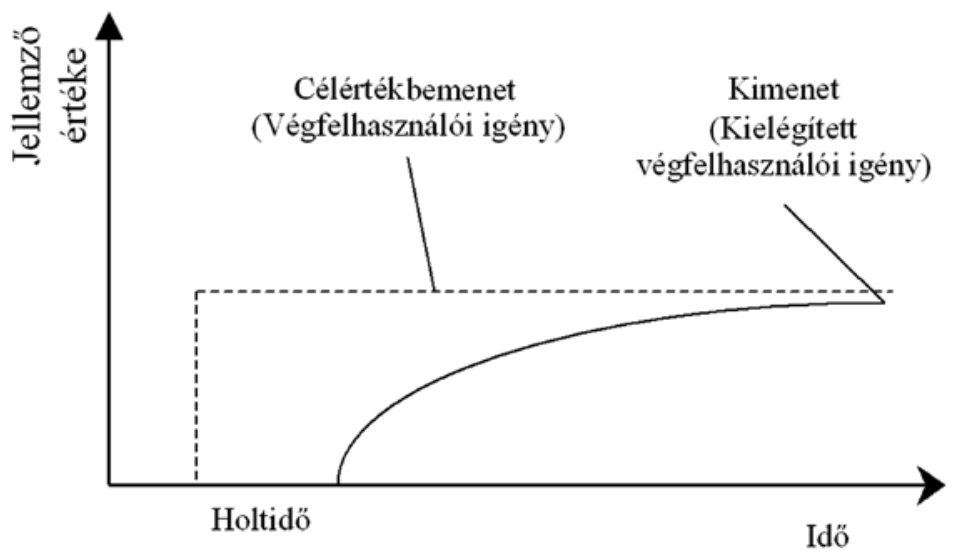

ség várható értéke. Egy váratlan igény megugrási esetére mutatja ezt a 2. ábra.

Ez az eset, ha a szabályozó beavatkozási energiája kicsi, emiatt több idôszakra van szükség a célállapot elérésére. Például a gyár kapacitása, vagy a rendelkezésre álló készlet túl kicsi lenne, idốbe telik, míg pótolják. A játékban a célérték elérése késleltetve ugyan, de egy lépésben megtörténhet. Ezt a gyár korlátlan kapacitása teszi lehetôvé, Ha a kiskereskedôi készlet meghaladja a mindenkori igényt, nincs holtidó, az igényt azonja kielégítik, hiány sem kit

A hiányt a játékban a két görbe különbsége szemlélteti. Sajátos helyzetet eredményez, hogy a kielégítetlen igény megmarad, hiányként időben gyúlik, integrálódik. A hiány ledolgozásához a pillanatnyi kimenet - az éppen kiszállított mennyiség - nagyobb lehet, holtidóből adódó késedelem esetén átmenetileg nagyobb kell, hogy legyen, mint a pillanatnyi igény (3. ábra). A továbbiakban feltételezzuik, hogy a hiany megmarad, a hiányköltség pedig nagyobb a készlettartási költségnél.

3. ábra Az átmeneti függvény hiány ledolgozása esetén ideális esetben

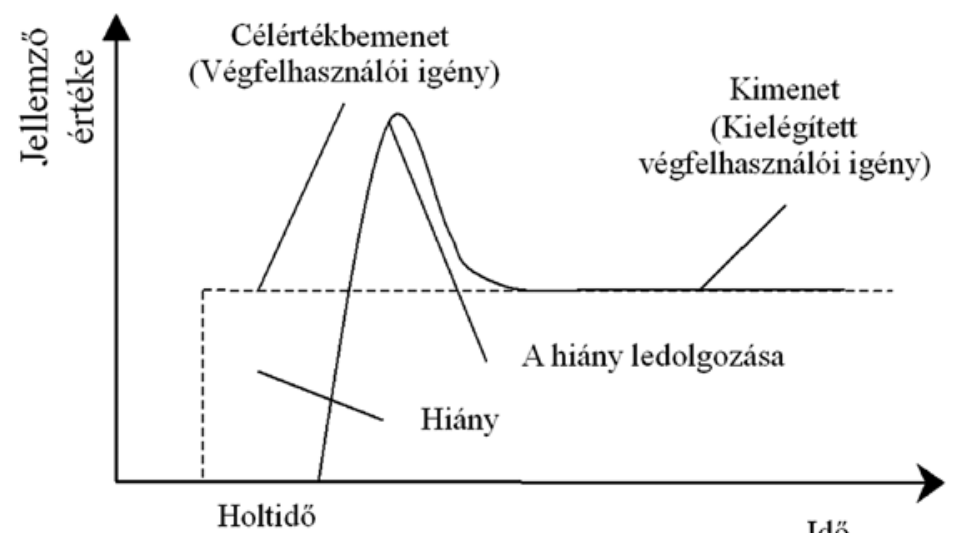

\section{VEZETÉSTUDOMÁNY}


A gyakorlatban nem sikerül mindig optimális dön- kozási energiája. Ebból a példából is látszik a koorditést hozni. Előfordul, hogy a döntéshozó túlkompen- náció, a résztvevớk feletti döntések szükségessége, a zálja a hiányt, vagyis a hiány ledolgozása érdekébe többet rendel. Ennek eredményeképpen magas készlet alakul ki, ami miatt átmenetileg vissza kell fogni a gyártást. Ez a túlkompenzáció annál inkább érdeke, minél nagyobb a hiányköltség a készlettartási költséghe képest. Ebben az esetben többet nyer a hiány korábbi ledolgozásával, mint amennyit a magasabb készletekkel veszít (4. ábra).

Az ábrák arra utalnak, hogy érdemes lenne valamilyen korlátot, például a gyár kapacitására egy felsô éréket tenni a rendszerbe.

A továbbiakban a múködést az alábbi mutatószámokkal jellemezzük: a játék során felmerült összes költség, időegységre jutó költség, legnagyobb készlet, legnagyobb hiány, átlagos készlet, átlagos hiány.

4. ábra Alapvetố jósági mutatónak az időegységjutó összes rendszerköltséget tekintjiik.

Az átmeneti függvény hiány ledolgozása esetén valós esetb

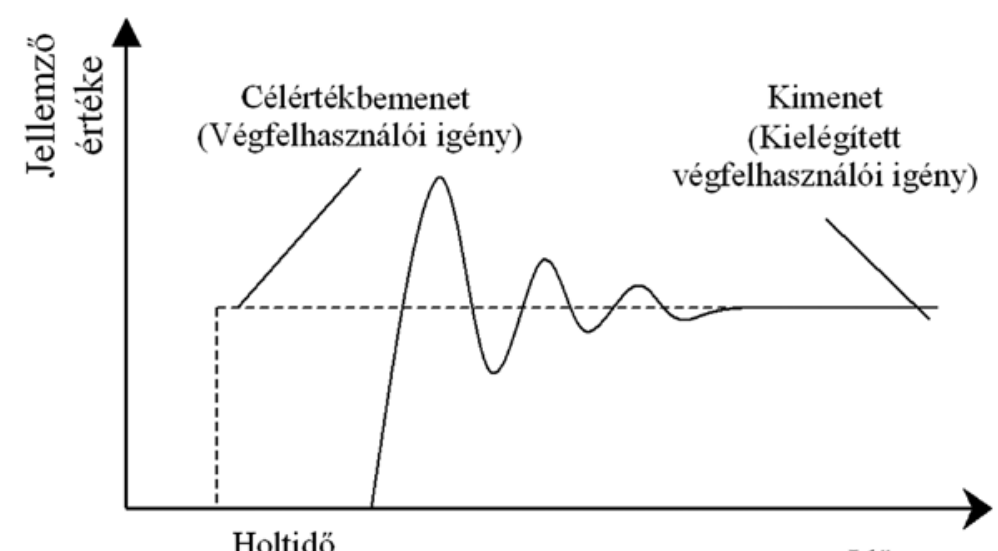

\section{Különbözố irányítási algoritmusok \\ hatása a múköóésre}

A sztochasztikus játék kapcsán ismert, a múszaki és gazdasági gyakorlatban régóta használt irányítási algoritmusokat próbáltunk ki. Ezek bemutatása után kitérünk még az ellátási lánc hosszának - a rendszer holtidejének - hatására.

A termék és idôegységre jutó készlettartási költség 0,5 euró, az ugyanilyen vonatkoztatású hiányköltség 1 euró. Az utánpótlási költségtől eltekintünk. A kezdókészlet mindegyik algoritmus esetén 5 egység.

Tekintettel arra, hogy az adott idôszaki készlet $=\quad$ A rendszer múködésének jóságát az időegységre - a $\begin{array}{ccc}\text { kezdókészlet }+ \text { addigi összes bevét a gyártásból }- \text { ad- } & \text { A rendszer múkódésenek jóságát az idóegységre - a } \\ \text { diszkrét szimulált idó miatt idószakra, ami a játékban }\end{array}$

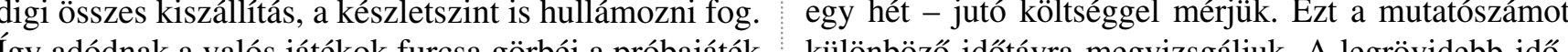

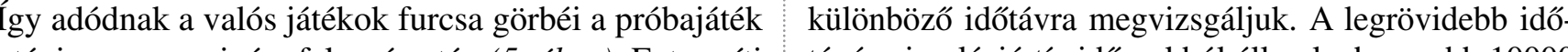
utáni egyszeres igényfelugrás után (5. ábra). Ezt segíti távú szimuláció tíz idôszakból áll, a leghosszabb 10000 az, ha a gyár kapacitása túl nagy, hozhat rossz döntést a idôszakból. A futtatások utáni statisztikai kiértékelés az termelés túlfuttatásával. A szabályzástechnika gyakor- 1. táblázatban látható adatokat szolgáltatja (1. táblázat). latában ez azt jelenti, hogy nagy a szabályozó beavat-

A futtatásokat többször megismételve a hosszú távú 5. ábra adatok (10000 időegység) kevéssé változnak, a rövid távúak erósebben. Ezek szórása érdekes további kérdéseket vet fel. Bár 10 ismétlésre ezeket bemutatjuk, azonban terjedelmi okokból ezek részletesebb elem-

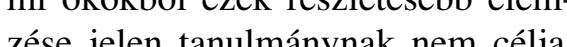
Avaló jút Avalos jatekok ámanch 35 idôszakig tartanak. A diagramokon az idó fuggvenyeben az igényt, a rendelest, valamint a készletet és a hiányt tüntetjük fel. Utóbbi kettố mutatja legjobban a rendszer állapotát, és egyúttal utal a költségekre is. Az igeny természete mindegyik esetben azonos: 0 és 20 közötti egyenletes eloszlás. Normális eloszlást alkalmazva a szimuláci-
A futtatási eredmények

\begin{tabular}{|l|l|l|l|l|}
\hline $\begin{array}{c}\text { A szimulált idószak } \\
\text { hossza }\end{array}$ & \multicolumn{1}{|c|}{$\mathbf{1 0}$} & \multicolumn{1}{|c|}{$\mathbf{1 0 0}$} & \multicolumn{1}{|c|}{$\mathbf{1 0 0 0}$} & \multicolumn{1}{|c|}{$\mathbf{1 0 0 0 0}$} \\
\hline Költség & 56 & 2144,5 & 18733,5 & 176257 \\
\hline Költség/idószak & 5,6 & 21,445 & 18,7335 & 17,6257 \\
\hline Legnagyobb & & & & \\
\hline Készlet & 19 & 76 & 91 & 101 \\
\hline Hiány & 0 & 74 & 74 & 76 \\
\hline Átlag & & & & \\
\hline Készlet & 11,2 & 12,45 & 17,895 & 18,4076 \\
\hline Hiány & 0 & 15,22 & 9,786 & 8,4219 \\
\hline ók során hasonló eredményet
\end{tabular}

kaptunk. Az egyenletes eloszlás kaptunk. Az egyenletes eloszlás alkalmazásanak magyarázata az hogy az osztálytermi játék során a véletlen számokat elsố alkalommal - a sztochasztikus játé ötletével egy idôben - egy helyszínen elkészített kártyakötegge állítottuk elő, és a továbbiakba ezt a köteget megtartottuk. A jó kommunikációs lehetőségek miatt rövid (2 ciklus) rendeléseljuttáxi idôvel számolunk, de a fiziki szállísi

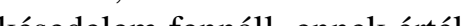
késedelen fennál, ennek éték mindegyik esetben 10. Avégfehasználó igény felmerüléseko azonnal ismertté válik minde résztvevő számára.

\section{Vezérlés}

Ez egy visszacsatolást nem tartalmazó, vezérlésjellegú irányítás. $\mathrm{Az}$ angol nyelvú szakirodalomban open loop néven jelenik meg. Azonos idóközönként ugyanolya mennyiséggel történik az utánpótlás. Esetiinkben ez azt jelenti, poras. Eśr i.tem. $\mathrm{A}$ kés uten. A készlet) mellek elméletében ezt $(1, q)$ mechanizmusnak nevezik, ahol $\mathrm{T}$ az álandó rendelési idốköz, q pedig az állandó rendelési tétel (6. ábra).

A különböző futtatások eredménye változatos képet mutat. A véletlen igények kiszámíthatatlanul viselkedô rendszert l.táblázat eredményeztek A jelenség hasonló az útmodellhez. A különbség az, hogy itt nincs pozitív - egyébkent semmilyen - visszacsatolás.

A készlet kiegyenlitó hatása nem tudott érvényesülni, pedig az - állandó - gyártási ütem megegyezett az igények átlagával (2. táblázat). A futtatásokat többször megismételve (3. táblázat).

A többi algoritmussal ellentétben itt elsốsorban nem a rövid, hanem a hosszú távú viselkedés szélsőséges. A rövid távú viselkedés a gyakorlatban megvalósuló más algoritmusokkal szemben érdekes - váratlanul jó - eredményeket ad. Ezt a Kovács (2010) munkábun

ábra

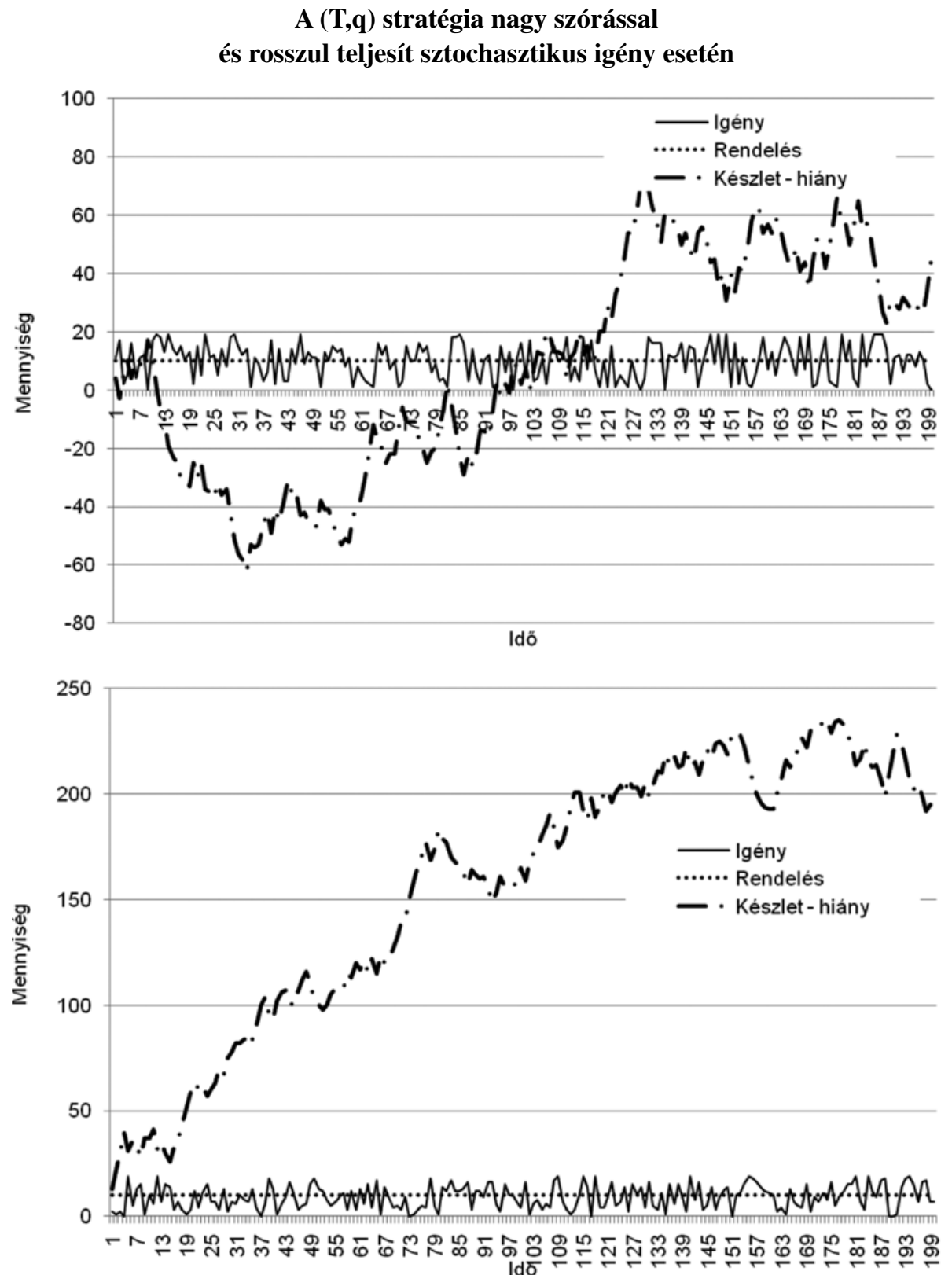


Eoy futtatás eredményei

\begin{tabular}{|l|l|l|l|l|}
\hline $\begin{array}{c}\text { A szimulált idố- } \\
\text { szak hossza }\end{array}$ & \multicolumn{1}{|c|}{$\mathbf{1 0}$} & \multicolumn{1}{|c|}{$\mathbf{1 0 0}$} & \multicolumn{1}{|c|}{$\mathbf{1 0 0 0}$} & \multicolumn{1}{|c|}{$\mathbf{1 0 0 0 0}$} \\
\hline Költség & 55 & 1657,5 & 122087,5 & 14455000 \\
\hline Költség/idószzak & 5,5 & 16,575 & 122,0875 & 1445,5 \\
\hline Legnagyobb & & & & \\
\hline Készlet & 10 & 45 & 443 & 6110 \\
\hline Hiány & 19 & 40 & 40 & 40 \\
\hline Átlag & & & & \\
\hline Készlet & 2 & 6,19 & 241,479 & 2890,73 \\
\hline Hiány & 4,5 & 13,48 & 1,348 & 0,1348 \\
\hline
\end{tabular}

Több futtatás eredményei

\begin{tabular}{|c|l|l|l|l|}
\hline & \multicolumn{5}{|c|}{ Költség/dóószak } \\
\hline Idószak & \multicolumn{1}{|c|}{$\mathbf{1 0}$} & \multicolumn{1}{|c|}{$\mathbf{1 0 0}$} & \multicolumn{1}{|c|}{$\mathbf{1 0 0 0}$} & \multicolumn{1}{|c|}{$\mathbf{1 0 0 0 0}$} \\
\hline 1 & 5,6 & 30,205 & 185,5335 & 1189,346 \\
\hline 2 & 11,65 & 29,365 & 268,8835 & 1407,335 \\
\hline 3 & 15,15 & 14,87 & 122,0595 & 1313,454 \\
\hline 4 & 5,6 & 30,26 & 175,7305 & 940,4632 \\
\hline 5 & 7,8 & 10,8 & 167,378 & 1314,387 \\
\hline 6 & 2,35 & 11,3 & 62,522 & 1107,864 \\
\hline 7 & 6,3 & 16,785 & 159,47 & 1143,236 \\
\hline 8 & 7,65 & 12,16 & 167,7315 & 1319,496 \\
\hline 9 & 9,5 & 39,595 & 170,502 & 1185,479 \\
\hline 10 & 5,7 & 30,96 & 83,7355 & 1245,241 \\
\hline Átlag & 7,73 & 22,63 & 156,3546 & 1216,63 \\
\hline Szórás & 3,617104 & 10,49062 & 57,35333 & 134,1224 \\
\hline
\end{tabular}

. összes modell azonos eredményt ad.

\section{Közvetlen visszacsatolás, a fogyás szerint} rendelés

Ez az algoritmus már figyelembe veszi a fogyást, mégpedig olyan módon, hogy mindegyik időszakban annyit rendel, amennyi akkor a kivét volt. A beérkezés a lánc hosszának megfeleló késéssel történik (7. ábra).

A kisebb ingadozásból adódóan jóval kisebb lett az egy idôszakra jutó költség: hosszú távon tekintve 1445,5-róll (átlag 1216) 13-ra csök-

Csak a kezdôkészlet állapítható meg szabadon (4. táblázat)

Egy futtatás eredménye

táblázat

\begin{tabular}{|l|c|c|c|l|}
\hline $\begin{array}{c}\text { A szimulált } \\
\text { idószak hossza }\end{array}$ & \multicolumn{10}{|c|}{} & $\mathbf{1 0 0}$ & $\mathbf{1 0 0 0}$ & $\mathbf{1 0 ~ 0 0 0}$ \\
\hline Költség & 44 & 839 & 10217,5 & 94931 \\
\hline Költséǵg/idószak & 4,4 & 8,39 & 10,2175 & 9,4931 \\
\hline Legnagyobb & & & & \\
\hline Készlet & 13 & 31 & 65 & 69 \\
\hline Hiány & 0 & 32 & 47 & 53 \\
\hline Átlag & & & & \\
\hline Készlet & 8,8 & 6,18 & 12,045 & 13,074 \\
\hline Hiány & 0 & 5,3 & 4,195 & 2,9561 \\
\hline
\end{tabular}

Az azonnali visszacsatolás

7. ábra kisebb szabályozási ingadozást eredményez

Az irányító számára nincs sok lehetốség optimalizálásra. A kezdókészletet meghatározhatja, de a jósága csak utólag dönthetô el. Elvileg a rendelési tételnagyságot is meghatározá,

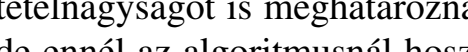
szú távon nincs értelme eltérni az atlagos igenytô. A rendelési tételnagyságot a rendelési idốkozzel egyult lehet váloztatn úgy, hogy a kettő hányadosa állandó maradjon.

A holtidô - szállítási késedelem - miatt az elsố 10 idószakban még a 'korábban' megrendelt 10 egység érkezik be, tehát

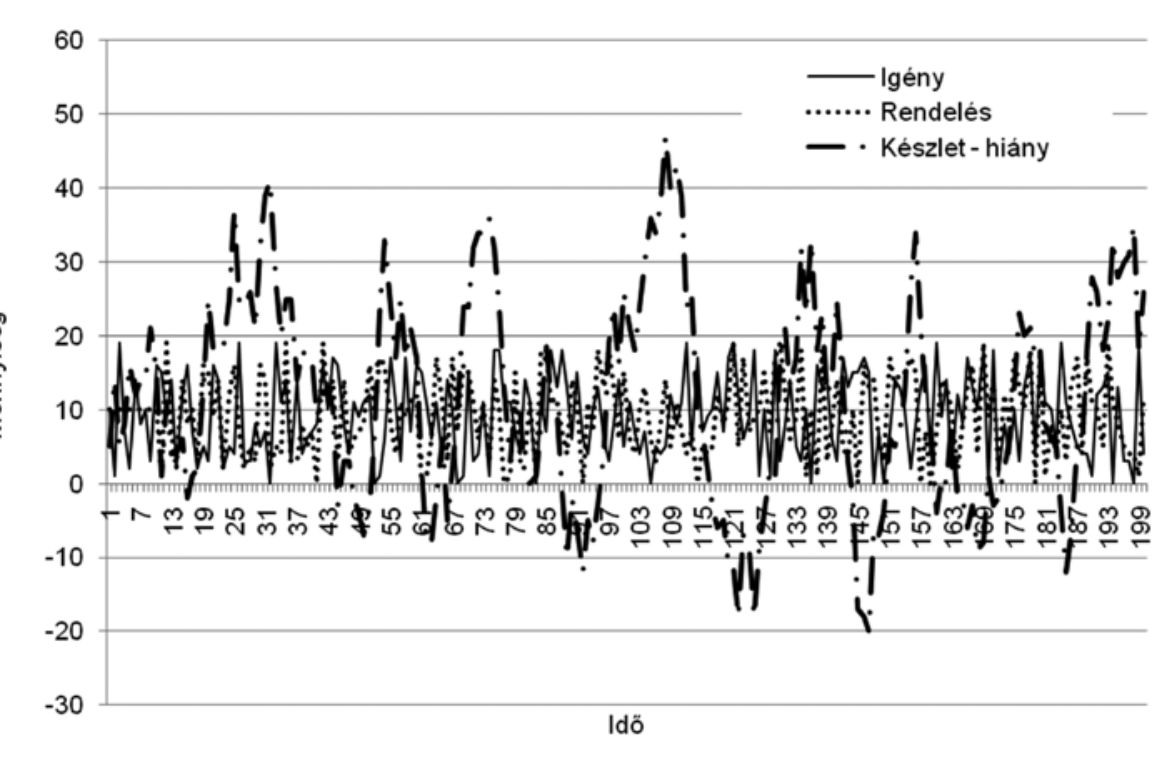

VEZETÉ STUDOMÁNY
8. ábra Két beavatkozási határértéket artalmazó állásos szabályozás A múszaki gyakorlatból jól ismert szabályozási forma. A menedzsmentgyakorlatban a kivételek elvével történő vezetésnek felel meg. Ha szabályozott az érték, ami itt a készletszint alsó és felső értéke között van, akkor nincs beavatkozás. Ha az alsó alá, vagy a felsố fölé megy, akkor történik rendelés, esetiintben a gyáttól, ami rendelést a szálítási idóból adó késedelem-

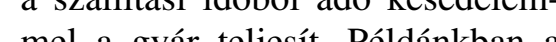
felsố beavar teljesít. Pêdánkan a felsó beavatkozási határ 6 , az alsó 4. Tekintettel arra, hogy fogyásra mindig lehet számítani, továbbá az utánpótlási költség 0 , ezért a két érték közötti készlet esetén is van rendelés, ami 10. Az alsó készletér9. ábra ték alatt a rendelés 15 , a felső feletti 5 (8. ábra).

A célérték tartására irányuló törekvés lengést eredményezhet

A pontozott vonal jól mutatja a szabályozás állásos jellegét, a kiés bekapcsolásokat, pontosabban a fel- és lekapcsolásokat. Vegyük észre, hogy készletszint alig van a kapcsolási rések között, csak induláskor van 10-es rendelés.

A készlet és a hiány legnagyobb értéke adja a szabályozási rést. A beavatkozási határok a kapcsolási rést határozzák meg. Az adott paraméterú állásos szabályozás rövid távon hasonló eredményt adott, mint a visszacsatolásos, hosszú távon roszszabb eredményt adó szabályozás.

A beavatkozás optimalizálható a kezdókészlet, a beavatkozási ha$-200$

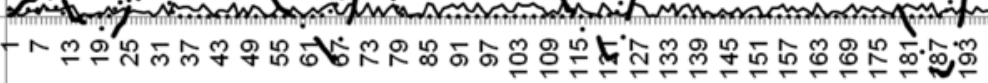

$-200$

tábláza

Egy futtatás eredménye

\begin{tabular}{|l|l|c|c|c|}
\hline A szimulált idószzak hossza & \multicolumn{1}{|c|}{$\mathbf{1 0}$} & $\mathbf{1 0 0}$ & \multicolumn{1}{|c|}{$\mathbf{1 0 0 0}$} & \multicolumn{1}{|c|}{$\mathbf{1 0 0 0 0}$} \\
\hline Költsé́g & 129 & 1744,5 & 17561 & 171687,5 \\
\hline Költség/idószak & 12,9 & 17,445 & 17,561 & 17,16875 \\
\hline Legnagyobb & \multicolumn{5}{|l|}{} \\
\hline Kézzlet & 38 & 65 & 87 & 103 \\
\hline Hiány & 0 & 44 & 80 & 80 \\
\hline Átlag & 25,8 & 15,55 & 17,784 & 17,6833 \\
\hline Készlet & 0 & 9,67 & 8,669 & 8,3271 \\
\hline Hiány &
\end{tabular}
tárok és értékek a határokat 4-re és 6-ra, a határokon kívïli beavatkoź́sí étćkeket pedig 8 -ra és 12 -revessulk 10000 kísérletnél az összes költség 13 alatt lesz (5. táblázat).

Egy célértéket tartalmazó visszacsatolás

A tartandó értéket adjuk meg kezdókészletnek. Ez esetünkben 5. Annyit tervez a gyár, hogy tartsa a kezdốkészletet. Ebben az esetben gyártás $=$ a fogyás várható értéke + ami hiányzik a kezdôkészlethez. A beérkezés - a többi esethez hasonlóan - késleltetve történik (9.ábra). 
Egy futtatás eredményei

\begin{tabular}{|l|l|l|l|l|}
\hline $\begin{array}{c}\text { A szimulált idốszak } \\
\text { hossza }\end{array}$ & \multicolumn{1}{|c|}{$\mathbf{1 0}$} & \multicolumn{1}{|c|}{$\mathbf{1 0 0}$} & \multicolumn{1}{|c|}{$\mathbf{1 0 0 0}$} & $\mathbf{1 0 0 0 0}$ \\
\hline Költség & 96,5 & 6104 & 118322,5 & 1128913 \\
\hline Költség/idószak & 9,65 & 61,04 & 118,3225 & 112,8913 \\
\hline Legnagyobb \\
\hline Készlet & 30 & 365 & 683 & 718 \\
\hline Hiány & 0 & 63 & 107 & 110 \\
\hline Átlag & 197 \\
\hline Készlet & 19,3 & 112,06 & 222,707 & 212,2852 \\
\hline Hiány & 0 & 5,01 & 6,969 & 6,7487 \\
\hline
\end{tabular}

A játékok eredményei

7. táblázat

\begin{tabular}{|l|c|c|}
\multicolumn{3}{|c|}{ A játékok eredményei } \\
\cline { 2 - 3 } \multicolumn{2}{|c|}{ Csapat } & \multicolumn{2}{|c|}{ Összes költség } \\
\cline { 2 - 3 } & Elórejelzés nélkül & Elörejelzzéssel 5 idószakra \\
\hline Arany Ászok & 67,1 & 3,8 \\
\hline Dimeszoan & 96,1 & 2,9 \\
\hline Löwenbrau & 29,4 & 1,2 \\
\hline Staropramen & 48,2 & 7,2 \\
\hline Sörcsap-at & 62,2 & 0,9 \\
\hline Arany Ászok & 67,1 & 3,8 \\
\hline Dreher & 27,0 & 14,6 \\
\hline Fekete Ökör & 16,0 & 8,1 \\
\hline Soproni & 24,2 & 8,5 \\
\hline Beer-ke & 24,2 & 5,5 \\
\hline Beerodalom & 24,5 & 18,2 \\
\hline Szalon Bambi & 54,5 & 14,3 \\
\hline
\end{tabular}

A adatok ábrázolása alapján úgy túnik, hogy az eddig tárgyaltak közül ez az algoritmus hasonlít leginkább ahhoz, amit a játékosok világszerte követnek. Az 5. ábrán a felsố diagramsor Az idő előrehaladtával a rendszer állapota romlik, mert a kilengések nônek (ostorsaṕrt

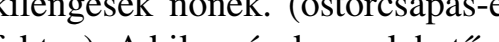
fektus). A kilengesek meglehetösen irányába (6. táblázat)

Az elórejelzés hatása

Az előrejelzési információ többféle lehet. Rövid idốtávra viszonylag pontos információ állhat rendelkezésre, hosszabb távon általában nô az előrejelzési információ bizonytalansága. Az elôrejelzés teszi

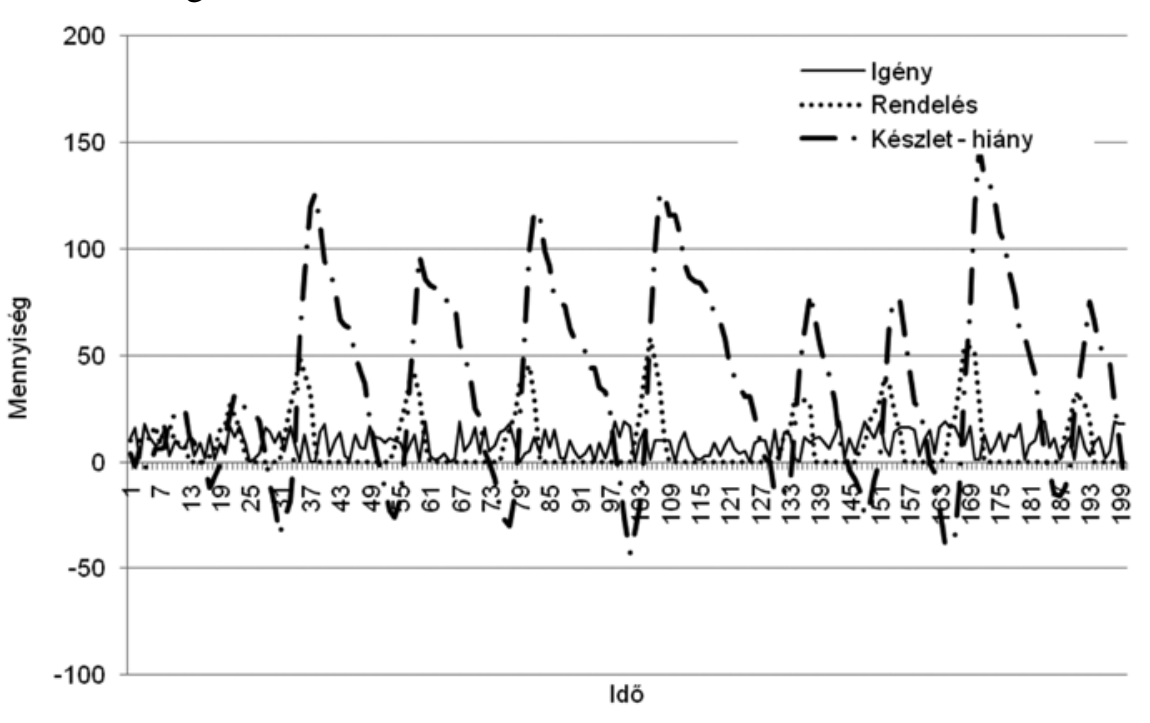

VEZETÉSTUDOMÁNY

8. táblázat

Eoy futtatás eredményei

\begin{tabular}{|c|c|c|c|c|c|}
\hline $\begin{array}{l}\text { A szimulált idốszak } \\
\text { hossza }\end{array}$ & 10 & 100 & \multicolumn{2}{|c|}{1000} & 10000 \\
\hline Költség & 40 & 2386 & \multicolumn{2}{|c|}{24471,5} & 232148,5 \\
\hline Költség/időszzak & 4 & 23,86 & \multicolumn{2}{|c|}{24,4715} & 23,21485 \\
\hline \multicolumn{6}{|l|}{ Legnagyobb } \\
\hline Készlet & 18 & 129 & \multicolumn{2}{|l|}{145} & 167 \\
\hline Hiány & 2 & 46 & \multicolumn{2}{|l|}{52} & 52 \\
\hline \multicolumn{6}{|l|}{ Átlag } \\
\hline Készlet & 7,6 & 37,12 & \multicolumn{2}{|c|}{38,795} & 37,2583 \\
\hline Hiány & 0,2 & 5,3 & \multicolumn{2}{|c|}{5,074} & 4,5857 \\
\hline \multicolumn{6}{|c|}{$\begin{array}{l}\text { A különbözó idôtánú futtatások } \\
\text { eredményei }\end{array}$} \\
\hline \multirow[t]{2}{*}{ Szabályozási mód } & Mutató & \multicolumn{4}{|c|}{ Költség/idốszak } \\
\hline & IIószzak & 10 & 100 & 1000 & 10000 \\
\hline \multirow[t]{2}{*}{ Vezérlés (T,q) } & Átlag & 7,73 & 22,63 & 156,35 & 1216,63 \\
\hline & Szórás & 3,62 & 10,49 & 57,35 & 134,12 \\
\hline \multirow[t]{2}{*}{ Közvetlen visszacsatolás } & Átlag & 6,85 & 9,33 & 9,43 & 9,53 \\
\hline & Szórás & 4,97 & 2,27 & 0,49 & 0,17 \\
\hline \multirow[t]{2}{*}{ Állásos szabályozás } & Átlag & 6,88 & 17,99 & 17,30 & 17,53 \\
\hline & Szórás & 3,31 & 3,60 & 0,66 & 0,43 \\
\hline \multirow[t]{2}{*}{ Célérték tartása, holtidó=10 } & Átlag & 6,68 & 93,11 & 114,51 & 113,83 \\
\hline & Szórás & 2,98 & 20,87 & 7,71 & 2,7784 \\
\hline \multirow[t]{2}{*}{ Célérték tartása,holtidó=5 } & Átlag & 9,00 & 20,16 & 22,86 & 23,02 \\
\hline & Szórás & 5,24 & 1,36 & 0,83 & 0,28 \\
\hline
\end{tabular}

A lánc hosszának felére csökkentése - hosszú idótávon - mintegy ötödére csökkentette a költségeket $(8$. táblázat).

Rövid távú viselkedés, szórások

A számítógépes szimulációs vizsgálatok egyik elōnyének tartják, hogy nagyszámú kísérletet elvégezve hosszú távra, átlagosan várható múköödés jelezhetố eló́ re. Altaláalgátanak.
nyeket szolgátana

A döntések azonban nem mindig szólnak hosszú távra, illetve ismétloódnek hosszú távon. Bár a szimulációt elsôsorban a hosszú távú viselkedés tanulmányozására használjuk, de egyik erơssége éppen a rövid távú viselkedés lehetséges kimeneteleinek, ezek szóródásának előállítása. A gyakorlatban a menedzsment sem mindig hosszú távú célokat követ. E mögött lehet egyéni motiváció, de a lerövidült termék-életciklusok is a rövid időtávú, kevés ciklusismétlődésủ döntések felértékelốdését eredményezik.
A korábban bemutatott futtatásokat tízszer megismételtük, más véletlen számokkal. A kapott eredmények átlagait és szórásait a 9. táblázat tartalmazza.

A holtidôvel összevethetố 10 idôegység-idótávon kicsi az egyes szabályozási algoritmusok teljesítóképessége közötti különbség. A (T,q) esetet leszámítva a kísérletek lépésszámának növekedésével az egyes kísérletek által szolgáltatott eredmények szórása csökken.

\section{Következtetése}

A különböző algoritmusok alkalmazása során az alapvető rendszerstruktúrát változatlannak tételeztük fel. Azonos volt a szereplő́k száma, a kapcsolat jellege, az egyes lépések és tevékenységek tartalma, idóigénye. A szabadon megválaszthatố paramétereket a 10. táblázat tartalmazza.

10. táblázat

Az egyes algoritmusok alkalmazása sorá

szabadon megválastható paraméterek

\begin{tabular}{|l|l|}
\hline \multicolumn{1}{|c|}{ Algoritmus } & \multicolumn{1}{c|}{ Választható paraméterek } \\
\hline (T,q) & $\begin{array}{l}\text { Kezdókészlet, } \\
\text { (állandó rendelési mennyiség) }\end{array}$ \\
\hline $\begin{array}{l}\text { A fogyás függvényé- } \\
\text { ben }\end{array}$ & Kezdókészlet \\
\hline Állásos & $\begin{array}{l}\text { Kezdókészlet, alsó határ, } \\
\text { felsố határ, alsó, közbuilsốs és } \\
\text { felsó beavatkozási értékek }\end{array}$ \\
\hline Értéktartó & Kezdókészlet \\
\hline Elớrecsatolás & Az elórejelzési idótátá \\
\hline
\end{tabular}

Az időegységre jutó költségeket tekintve hosszú távon a legjobbnak a fogyás szerinti utánpótlás bizonyult. Ezután az állásos algoritmus, majd a készletszintet tartani kívánó szabályozás következik.

Elképzelhetô, hogy a paraméterek javításával jobb ékek kaphatók, ami befolyásolná a sorrendet. $A$ jónc csökkentése arányost meghaladó eredménynyel járt.

$A(T, q)$ stratégia rövid távon, jól megválasztott kezđókészlet esetén lehet eredményes. Erre utal az is, hogy övid - 10 idóegység - távon a $(\mathrm{T}, \mathrm{q})$ szerinti ismételt játékok költségének szórása közel azonos a többi algoritmus esetén kapottal. A gyakorlatban kivitelezett játékok során rövid idôtávon (10-15 ciklus) a tanár által vitt $(\mathrm{T}, \mathrm{q})$ stratégia kevés kivétellel jobbnak bizonyult a resztvevốk által - bonyolultsága miatt hibákkal megvalósított - fejlettebb, általában visszacsatolást tartalmazó stratégiáknál. Az egyszerúség úgy is megvalósítható,

\section{VEZETÉSTUDOMÁN}


hogy alapvetóen (T,q) stratégiát visznek, és bizonyos idôközönként, például 10 idôegység eltelte után történik - visszacsatolásos - beavatkozás, ami során visszatérítik a rendszert egy megfelelő állapotba.

Az ilyen stratégia vizsgálatához kimondottan jó eszköz a Monte Carlo szimuláció, ami ebben az esetben úgy is tekinthetố, mint a rövid távú lehetséges viselkedések előállítására szolgáló eszköz, egyfajta szcenárió generátor.

A gazdaságban - makro- és mikroszinten - egyaránt több olyan folyamat van, ami a fenti modellek valamelyikével írható le. Például a jelentős beszerzési idejú anyagok készleteivel történố gazdálkodás. Itt nem is kell az egész láncot tekinteni, elég csak egy készletezési helyet.

Ezeket kombinálni is lehetne: bizonyos idôszakonként visszacsatolással (helyre)állítani a múködési körülményeket (korrekció), ezek között pedig egyszerú vezérlést alkalmazni.

A szabályozók, szabályzatok készítésekor meg kell fontolni az egyes esetekben alkalmazandó döntési szabályokat. Fontos figyelembe venni a beavatkozás és annak hatása közötti holtidôt, ezt lehetőség szerint csökkenteni kell.

Törekedni kell előrejelzési információk gyújtésére és felhasználására, ahol lehetséges, preventív előrecsatolást kell alkalmazni. Ha a rendszer holtideje viszonylag hosszú, a döntési helyzet pedig nem ismétlődik hosszú távon, érdemesebb egyszerú, de biztonságosan megvalósítható szabályt alkalmazni, mint valamenynyivel jobb eredménnyel járó, de könnyen elhibázható algoritmust.

Jelen cikkben nem foglalkoztunk azzal a fontos kérdéssel, hogy a közös, rendszerszintú optimumot hogyan lehet elfogadtatni az ellátási lánc minden szereplöjével, akik között vannak olyanok, akik számára a saját optimum követése jobb eredményt adna.

\section{Lábjegyzet}

${ }^{1}$ Cikkünk a TÁMOP 4.2.2. projekt keretében történő disszeminációnak is része.

\section{Felhasznált irodalom}

Chikán A. (1997): Vállalatgazdaságtan. AULA, Budapest Coakley, J.R. - Drexler, J.A. - Larson, E.W. - Kircher, A.E. (1998): Using a Computer-Based Version of the Beer Game: Lessons Learned. Journal of Management Education, Vol. 22, No. 3, p. 416-424.

D'atri, A. - Spagnoletti, P. - Banzato, A. - Bonelli C. D'atri, E. - Traversi, V. - Zeno, P. (2009): Supply Chain and Virtual Enterprises: the Beer Game evolution, Proceedings Proceedings of ALPIS. Sprouts: Working Papers on Information Systems, 9(13). http://sprouts. aisnet.org/9-13, 2010. január 22.

Forrester, J. (1961): Industrial Dynamics. MIT Press, Cambridge, $\mathrm{MA}$

Goetgeluk, J. (2006): StochasticProgrammingIn SupplyChain Management, PhD Thesis, http://lib.ugent.be/fulltxt/ RUG01/001/311/912/RUG01-001311912_2010_0001_ AC.pdf, 2010. október 28.

Goodwin, J.S. - Franklin, S.G. (1994): The Beer Distribution Game: Using Simulation to Teach Systems Thinking. Journal of Management Development, MCB UP Ltd. Vol. 13, Issue 8, p. 7-15.

Kovács Z. (2010): Egy ellátási lánc szimulációjának tapasztalatai. Vezetéstudomány, 41. évf. 10. szám, 2010, p 53-61.

Kumar, S. - Chandra, Ch. - Seppanen, M.S. (2007): Demonstrating supply chain parameter optimization through beer game simulation, Information-KnowledgeSystems Management. Volume 6, Issue 4, IOS Press Amsterdam, p. 291-322

Noy, A. - Ranan, D. - Ravid, G. (2006): Testing Social Theories, Simulation \& Gaming. Vol. 37, No. 2,June, p. 174-194.

Senge, P.M. (1990): The Fifth Discipline: The Art \& Practice of the Learning Organization. Doubleday Business, London

Sterman, J.D. (1992): Teaching Takes Off: Flight Simulators for Management Education. OR/MS Today, p. 40-44. - http://www.martin-christopher.info/about.htm

Cikk beérkezett: 2010. 11. hó

Lektori vélemény alapján véglegesítve: 2011. 6. hó 